\title{
PENERAPAN MODEL PEMBELAJARAN KOOPERATIF TIPE TALKING CHIPS UNTUK MENINGKATKAN AKTIVITAS BELAJAR DAN HASIL BELAJAR SISWA PADA MATA PELAJARAN EKONOMI SISWA KELAS X DI SMA SARASWATI SINGARAJA TAHUN PELAJARAN 2017/2018
}

\author{
Yuliana Wati Dewi \\ Jurusan Pendidikan Ekonomi \\ Universitas Pendidikan Ganesha \\ Singaraja, Indonesia \\ e-mail : yuliana watidewi@yahoo.co.id
}

\begin{abstract}
Abstrak
Penelitian ini bertujuan untuk mengetahui peningkatan aktivitas dan hasil belajar siswa melalui penerapan model pembelajaran talking chips pada mata pelajaran Ekonomi di kelas X SMA Saraswati Singaraja tahun ajaran 2017/2018. Penelitian ini termasuk penelitian tindakan kelas yang dilaksanakan dalam dua siklus dengan tahapan-tahapan setiap siklus meliputi perencanaan, pelaksanaan, observasi, pengamatan dan refleksi. Data aktivitas belajar siswa dikumpulkan dengan menggunakan metode observasi, sedangkan data hasil belajar dikumpulkan melalui metode tes yang dianalisis dengan menggunakan analisis deskriptif kuantitatif. Hasil penelitian menunjukkan bahwa (1) penerapan model pembelajaran talking chips dapat meningkatkan aktivitas belajar siswa yang ditunjukkan dengan rata-rata skor aktivitas belajar siklus I dengan kategori cukup aktif selanjutnya meningkat dengan kategori aktif pada siklus II. (2) penerapan model pembelajaran talking chips dapat meningkatkan hasil belajar siswa yang ditunjukkan dengan rata-rata skor hasil belajar siklus I sebesar 70,65 dengan kategori cukup selanjutnya meningkat menjadi 80,65 dengan kategori baik pada siklus II.
\end{abstract}

Kata kunci : Aktivitas, Hasil Belajar, Talking Chips

\begin{abstract}
This research was aimed to find out Students' rising activities and students' learning outcomes based on cooperative learning through talking chips method to the students of class X Saraswati Highschool (SMA) Singaraja on period 2017/2018 for Economic Lesson. This was kind of classroom action research which held in two cycles with some steps, they are: planning, implementing, observing, monitoring, and reflecting. The students' activities data was submitted by using observation method while the students' outcomes data was submitted by applying test method which analyzed through descriptive quantitative method. The outcomes shown (1) implementing the talking chips model in learning method can rise students' activities which proven by the students' average scores in learning cycle I with 'quite active' category and then increase to 'active category in cycle II. (2) implementing this learning model can rise students' average scores from 70.65 in 'quite active' category for cycle I to 80.65 in 'active' category for cycle II.
\end{abstract}

Keywords: Learning Activities, Learning Outcomes, Talking Chips 


\section{PENDAHULUAN}

Perkembangan IImu Pengetahuan dan Teknologi (IPTEK) dalam era globalisasi sudah mengalami kemajuan yang pesat. Persaingan dalam berbagai bidang menuntut seluruh masyarakat untuk memantapkan diri dalam meningkatkan kualitas Sumber Daya Manusia (SDM) yang unggul, menguasai ilmu pengetahuan dan teknologi, serta mampu berdaya saing dalam menghadapi tantangan kehidupan yang semakin berat. Atas dasar tuntutan mewujudkan masyarakat yang seperti itu, maka diperlukan upaya peningkatan kualitas SDM yakni melalui peningkatan mutu pendidikan.

Pendidikan adalah salah satu bentuk perwujudan kebudayaan manusia yang dinamis oleh sarat perkembangan. Oleh karena itu, perubahan atau perkembangan pendidikan adalah hal yang memang seharusnya terjadi sejalan dengan perubahan budaya kehidupan" (Trianto, 2009:1). Menurut Mudyahardjo (dalam Sagala, 2009:3) "pendidikan ialah segala pengalaman belajar yang berlangsung dalam segala lingkungan dan sepanjang hidup serta pendidikan dapat diartikan sebagai pengajaran yang diselenggarakan di sekolah sebagai lembaga pendidikan formal". Dalam Undang-Undang Republik Indonesia Nomor 20 Tahun 2003 tentang Sistem Pendidikan Nasional (SISDIKNAS) bab II Pasal 3 disebutkan bahwa:

Pendidikan nasional berfungsi mengembangkan kemampuan dan membentuk watak serta peradaban bangsa yang bermartabat dalam rangka mencerdaskan kehidupan bangsa, bertujuan untuk berkembangnya potensi peserta didik agar menjadi manusia yang beriman dan bertakwa kepada Tuhan Yang Maha Esa, berakhlak mulia, sehat, beriman, cakap, kreatif, mandiri, dan menjadi warga negara yang demokratis serta bertanggung jawab.

Penyempurnaan kurikulum secara berkala diharapkan dapat memberikan sumbangan positif dalam upaya meningkatkan mutu pendidikan nasional.
Kurikulum yang berlaku sekarang adalah Kurikulum 2013 di SD, SMP, SMA dan lainlain. Kurikulum 2013 pada dasarnya adalah pengembangan dari kurikulum berbasis kompetensi. Kurikulum yang dikembangkan dengan berbasis pada kompetensi bertujuan untuk menjadikan peserta didik sebagai (1) manusia berkualitas yang mampu dan proaktif menjawab tantangan zaman yang selalu berubah, (2) manusia terdidik yang beriman dan bertakwa kepada Tuhan Yang Maha Esa, berakhlak mulia, sehat, berilmu, cakap, kreatif, mandiri, dan (3) warga negara yang demokratis dan bertanggung jawab. Untuk mendukung pencapaian tersebut maka pengembangan potensi peserta didik harus disesuaikan dengan potensi, perkembangan, kebutuhan, kepentingan peserta didik, serta keadaan dan tuntutan lingkungan di sekitarnya. Tuntutan pengembangan Kurikulum 2013 itu ditujukan kepada semua mata pelajaran termasuk mata pelajaran Ekonomi. Adapun tujuan dari pembelajaran Ekonomi menurut silabus pelajaran Ekonomi tahun 2013 di SMA/MA yaitu : (1) memiliki perilaku yang mencerminkan sikap orang beriman, berakhlak mulia, berilmu, percaya diri, dan bertanggung jawab dalam berinteraksi secara efektif dengan lingkungan sosial dan alam serta dalam menempatkan diri sebagai cerminan bangsa dalam pergaulan dunia, (2) memiliki pengetahuan faktual, konseptual, prosedural, dan metakognitif dalam ilmu pengetahuan, teknologi, seni dan budaya dengan wawasan kemanusian, kebangsaan, kenegaraan, dan peradaban terkait penyebab serta dampak fenomena dan kejadian, (3) memiliki kemampuan pikir dan tindak yang efektif dan kreatif dalam ranah abstrak dan konkret sebagai pengembangan dari yang dipelajari di sekolah secara mandiri.

Hasil penelitian awal pembelajaran Ekonomi yang dilakukan di kelas X SMA Saraswati dapat digambarkan proses pembelajaran belum mencapai tujuan yang maksimal, hal ini dapat dilihat dari hasil belajar siswa pada mata pelajaran Ekonomi. Rendahnya hasil belajar siswa tampak dari rata-rata nilai Ulangan Tengah Semester (UTS) siswa kelas X pada awal semester ganjil tahun pelajaran 2017/2018. Hal 
tersebut dapat dilihat dari rata-rata nilai hasil belajar mata pelajaran Ekonomi siswa kelas $X$ adalah 67,70 dengan nilai tertinggi 80 dan nilai terendah 50 sedangkan Kriteria Ketuntasan Minimal (KKM) untuk mata pelajaran Ekonomi di SMA Saraswati Singaraja adalah 70. Dari KKM tersebut dapat diketahui siswa yang sudah tuntas sebanyak 11 orang $(47,83 \%)$ dan siswa yang tidak tuntas sebanyak 12 orang $(52,17 \%)$, dengan jumlah siswa 23 orang.

Berdasarkan hasil penelitian awal tersebut, maka di butuhkan sebuah model pembelajaran. Arends (dalam Suprijono, memiliki empat ciri khusus yang tidak dimiliki oleh strategi, metode atau pendekatan bahkan teknik dan taktik pembelajaran.

Pengertian model pembelajaran talking chips menurut Lie (dalam Fathurrohman, 2015:93) adalah salah satu tipe model pembelajaran kooperatif yang masing-masing anggota kelompoknya mendapat kesempatan yang sama untuk memberikan kontribusi mereka dan mendengarkan pandangan serta pemikiran anggota kelompok lain. Dalam kegiatan talking chips, masing-masing anggota kelompok mendapat kesempatan untuk memberikan kontribusi mereka dan mendengarkan pandangan dan pemikiran anggota yang lain. Keunggulan lain dari teknik ini adalah untuk mengatasi hambatan pemerataan kesempatan yang sering mewarnai kerja kelompok.

Kagan (dalam Fathurrohman, 2015) menyatakan bahwa model pembelajaran kooperatif tipe talking chips adalah jenis metode struktural yang mengembangkan hubungan timbal balik antaranggota kelompok dengan didasari adanya kepentingan yang sama. Setiap anggota mendapatkan chips yang berbeda yang harus digunakan setiap kali mereka ingin berbicara menyatakan keraguan, menjawab pertayaan, bertanya, mengenai sesuatu, mengungkapkan ide, mengklarifikasi pernyataan, mengklarifikasi ide, merespon ide, merangkum, mendorong partisipasi anggota lainnya, dan memberikan penghargaan untuk ide yang dikemukakan anggota lainnya dengan mengatakan hal
2009:46) menyatakan bahwa "model pembelajaran mengacu pada pendekatan yang akan digunakan, termasuk di dalamnya tujuan pembelajaran, tahap-tahap dalam kegiatan pembelajaran, lingkungan pembelajaran, evaluasi dan pengelolaan kelas". Untuk memilih model ini sangat dipengaruhi oleh sifat dari materi yang akan diajarkan, dan juga dipengaruhi oleh tujuan yang akan dicapai dalam pengajaran tersebut serta tingkat karakteristik peserta didik. Di samping itu pula, setiap model pembelajaran juga mempunyai tahap-tahap (sintaks) yang dapat dilakukan siswa dengan bimbingan guru. $\quad$ Model yang positif. Sedangkan menurut Millis dan Cottel (dalam Fathurrohman, 2015) model teknik pembelajaran kooperatif tipe talking chips adalah jenis model pembelajaran kooperatif dengan cara siswa diberikan chips yang berfungsi sebagai tiket yang memberikan izin pemegangnya untuk berbagi informasi, berkontribusi pada diskusi, atau membuat titik debat.

Siswa dalam pembelajaran harus terlibat aktif, baik secara fisik maupun mental sehingga terjadi interaksi yang optimal antara guru dengan siswa dan siswa dengan siswa lainnya. Terdapat dua kriteria penting yang perlu dipahami untuk membedakan antara aktivitas pembelajaran dengan berbagai bentuk aktivitas lainnya. Kedua kriteria yang dimaksud adalah (1) aktivitas pembelajaran harus dirancang secara sengaja (intention) sebagai suatu tindakan yang dipersiapkan sebelumnya berdasarkan tujuan pembelajaran, sebagai kebalikan dari kegiatan yang dipilih secara acak, (2) harus dikelola dengan berbagai cara, termasuk yang dipersiapkan oleh peserta didik yang melibatkan usaha untuk mentransfer informasi dalam pengertian yang seluas-luasnya (pesan, ide, pengetahuan, dan strategi). Menurut Yaumi (2012), aktivitas dalam arti luas meliputi pendidikan praktik-praktik yang memperlakukan peserta didik bukan hanya sebagai pelaksana pembelajaran yang diberikan oleh pendidik, melainkan juga berperan sebagai agen tindakan kognitif yang didistribusikan antara pendidik dan peserta didik.

Hasil belajar merupakan sesuatu yang dialami seseorang untuk mencapai tujuan 
yang diinginkan sehingga tingkah lakunya mengalami perubahan ke hal yang lebih baik. Pernyataan tersebut didukung oleh Sudjana (Sukesih, 2003) yang menyatakan hasil belajar adalah kemampuan-kemampuan yang dimiliki siswa setelah menerima pengalaman belajarnya. Mudjiono, Dimyati (2006: 208) menyatakan bahwa hasil belajar merupakan suatu proses yang sitematis. Senada dengan pendapat tersebut, Bundu (2006:17) menyatakan "hasil belajar adalah perubahan tingkah laku individu yang relativ menetap sebagai hasil Pendapat tersebut didukung oleh Slameto (2003:54) yang menyatakan "faktor-faktor yang mempengaruhi hasil belajar banyak jenisnya, tetapi dapat digolongkan menjadi dua golongan saja, yaitu intern dan ekstern". Jadi dapat diketahui bahwa faktor-faktor yang mempengaruhi hasil belajar adalah faktor ekstern dan intern.

Rendahnya hasil belajar Ekonomi siswa yang terjadi di SMA Saraswati, jalan Bisma No. 4, Banjar Tegal, Singaraja Buleleng, disebabkan oleh beberapa faktor: (1) siswa kurang aktif bertanya pada saat guru menjelaskan materi (2) siswa hanya menjawab saat guru memberikan pertanyaan, (3) siswa kurang terbiasa belajar mandiri (4) dalam kegiatan diskusi siswa cenderung pasif.

\section{METODE}

Penelitian ini merupakan penelitian tindakan kelas (Classsrom Action Research) yang bertujuan untuk meningkatkan aktivitas dan hasil belajar siswa kelas X SMA Saraswati Singaraja tahun pelajaran 2017/2018 melalui penerapan model pembelajaran kooperatif tipe talking chips. Penelitian ini diawali dengan refleksi hasil pengamatan dan wawancara peneliti dengan guru mata pelajaran Ekonomi kelas X SMA Saraswati Singaraja tahun pelajaran 2017/2018, untuk dapat mengamati lebih jelas masalah yang terjadi dalam proses pembelajaran di kelas. Untuk mengatasi permasalahan dalam proses pembelajaran akan dilaksanakan tindakan yang terbagi menjadi 2 siklus dan setiap akhir siklus diadakan evaluasi. Dalam hal ini yang interaksi dengan lingkungan". Seorang yang belajar dipengaruhi oleh berbagai faktor baik itu dari dalam maupun faktor dari luar. Kedua faktor tersebut saling berkaitan yang dapat mempengaruhi hasil belajar siswa. Hal tersebut didukung oleh Daryanto (2009:51) yang menyatakan "faktor yang mempengaruhi belajar oleh faktor intern dan secara umum hasil belajar siswa dipengaruhi oleh faktor internal, yaitu faktor-faktor yang ada dalam diri siswa dan faktor eksternal, yaitu faktor -faktor yang berada di luar diri siswa".

dievaluasi adalah hasil belajar siswa dengan memberikan tes objektif serta mengevaluasi kendala-kendala dan kesulitan yang ditemukan selama pelaksanaan tindakan.

Berdasarkan data yang didapat jumlah siswa-siswi kelas $X$ di SMA Saraswati yang berjumlah 23 orang pada tahun 2017/2018. Dari jumlah tersebut terdapat 13 siswa lakilaki dan 10 siswa perempuan. Jenis data yang digunakan dalam penelitian ini adalah data kuantitatif. Data kuantitatif yang digunakan berupa data hasil belajar siswa dan data aktivitas belajar siswa yang telah dikuantitatifkan dalam penelitian.

Menurut, sumber data yang digunakan dalam penelitian ini adalah data primer. Data primer adalah data yang langsung didapatkan dari subjek penelitian, dalam hal ini berupa data aktivitas belajar dan data hasil belajar siswa terhadap penerapan model pembelajaran kooperatif tipe talking chips. Penelitian ini menggunakan metode tes yang instrumennya berupa soal-soal ujian atau soal-soal tes (Daryanto, 2012). Dalam penelitian ini, diperlukan metode tes untuk mengumpulkan data hasil belajar siswa dan tes yang digunakan untuk mengumpulkan data adalah tes akhir (post-test). Metode observasi juga diperlukan untuk mengumpulkan data aktivitas belajar siswa dalam proses pembelajaran dengan model pembelajaran talking chips. Alat pengumpulan datanya berupa lembar observasi. Dalam penelitian ini, metode dokumentasi juga dipergunakan untuk memperoleh data tentang hasil belajar siswa, foto atau rekaman proses belajar mengajar di kelas.

Analisis data untuk aktivitas belajar Ekonomi secara individu dianalisis 
berdasarkan presentase kemunculan tiap item aktivitas belajar kegiatan yang dilakukan siswa selama proses pembelajaran. Kriteria penggolongan aktivitas belajar disusun berdasarkan nilai rata-rata mean ideal (Mi), standar devisiasi ideal (Sdi) dan skor aktivitas belajar siswa $(\bar{x})$. Rumus untuk Mi dan Sdi adalah sebagai berikut.
Mi $=\frac{1}{2} \times$ (skor tertinggi ideal + skor terenda ideal)

Sdi $=\frac{1}{6} \times$ (skor tertinggi ideal - skor terendah ideal)

(Koyan, 2012)

Analisis data untuk mengetahui adanya peningkatan hasil belajar siswa pada siklus I, II dan seterusnya digunakan rumus sebagai berikut

a. Daya serap kompetensi pemahaman konsep siswa (DDS) menggunakan rumus:

$\mathrm{DSS}=\frac{\text { Jumlah tot al nilai y ang dicapa } i \text { siswa }}{\text { Jumlah tot al skor ma ksimum }} \times 100 \%$

b. Untuk mengetahui persentase ketuntasan belajar siswa secara klasikal akan dihitung dengan rumus sebagai berikut (Candiasa, 2010).

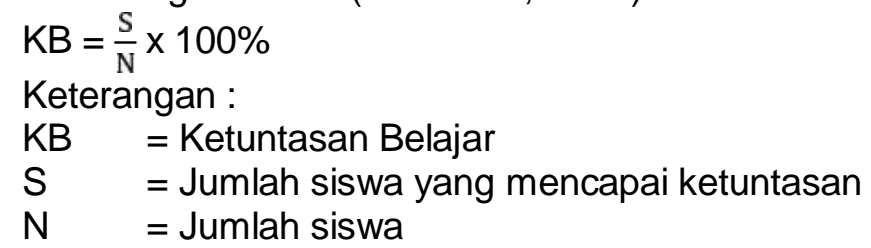

\section{HASIL DAN PEMBAHASAN}

Hasil

Perolehan data aktivitas belajar siswa kelas $X$ SMA Saraswati Singaraja yang berjumlah sebanyak 23 orang siswa pada siklus I pertemuan pertama diketahui bahwa, tidak ada siswa yang aktivitas belajarnya berada pada kategori sangat aktif, pada kategori aktif sebanyak 4 orang $(17,40 \%)$, pada kategori cukup aktif sebanyak 9 orang $(39,13 \%)$, pada kategori kurang aktif sebanyak 8 orang $(34,78 \%)$, dan pada kategori sangat kurang aktif sebanyak 2 orang $(8,70 \%)$. Pada pertemuan kedua, tidak ada siswa yang aktivitas belajarnya pada kategori sangat aktif, pada kategori aktif sebanyak 5 orang $(21,74 \%)$, pada kategori cukup aktif sebanyak 13 orang $(56,52 \%)$, pada kategori kurang aktif sebanyak 4 orang $(17,40)$ dan pada kategori sangat kurang aktif sebanyak 1 (4,35\%). Data aktivitas belajar siswa pertemuan pertama dan pertemuan kedua pada siklus I tampak $\begin{array}{llll}\text { pada } & \text { tabel } & 4.1 & \text { berikut }\end{array}$

Tabel 4.1 Data Aktivitas Belajar Siswa dalam Mata Pelajaran Ekonomi Siklus I

\begin{tabular}{ccccc}
\hline \multirow{2}{*}{ Kategori } & \multicolumn{3}{c}{ Sebaran Aktivitas Belajar Siswa } \\
\cline { 2 - 5 } & \multicolumn{2}{c}{ Pertemuan Pertama } & \multicolumn{2}{c}{ Pertemuan Kedua } \\
\cline { 2 - 5 } & $\begin{array}{c}\text { Jumlah } \\
\text { Siswa }\end{array}$ & Presentase & $\begin{array}{c}\text { Jumlah } \\
\text { Siswa }\end{array}$ & Persentase \\
\hline Sangat Aktif & 0 & $0 \%$ & 0 & $0 \%$ \\
Aktif & 4 & $17 \%$ & 5 & $22 \%$ \\
Cukup Aktif & 9 & $39 \%$ & 13 & $56 \%$ \\
Kurang Aktif & 8 & $35 \%$ & 4 & $17 \%$ \\
Sangat Kurang & 2 & $9 \%$ & 1 & $4 \%$ \\
Aktif & & $100 \%$ & 23 & $100 \%$ \\
Jumlah Siswa & 23 & & &
\end{tabular}


Hasil belajar siswa pada siklus I menunjukkan bahwa nilai tertinggi yang mampu dicapai oleh siswa adalah 85, sementara nilai terendah yang diperoleh siswa adalah 55. Siswa yang memperoleh nilai pada rentangan $85-100$ sebanyak 4 orang $(17,39 \%)$, siswa yang memperoleh nilai pada rentangan 75-84 sebanyak 7 orang $(30,43 \%)$, siswa yang memperoleh nilai pada rentangan $65-74$ sebanyak 5 orang $(21,74 \%)$, siswa yang memperoleh nilai pada rentangan 41-64 sebanyak 7 orang $(30,43 \%)$, dan tidak ada siswa yang memperoleh nilai pada rentangan 0-40. Rata-rata hasil belajar siswa pada siklus I adalah 70,65 dengan kategori hasil belajar adalah cukup. Data hasil belajar siswa pada siklus I tampak pada tabel 4.2 berikut.

Tabel 4.2 Data Hasil Belajar Siswa Ekonomi Siklus I

\begin{tabular}{|c|c|c|c|c|}
\hline No & $\begin{array}{c}\text { Rentangan } \\
\text { Nilai }\end{array}$ & Kategori Nilai & Jumlah Siswa & Persentase \\
\hline 1 & $85-100$ & Amat Baik & 4 & $17,39 \%$ \\
\hline 2 & $75-84$ & Baik & 7 & $30,43 \%$ \\
\hline 3 & $65-74$ & Cukup & 5 & $21,74 \%$ \\
\hline 4 & $41-64$ & Kurang & 7 & $30,43 \%$ \\
\hline 5 & $0-40$ & Sangat Kurang & 0 & $0,00 \%$ \\
\hline \multicolumn{3}{|c|}{ Total } & 23 & $100,00 \%$ \\
\hline
\end{tabular}

Berdasarkan hasil belajar siswa pada siklus I dapat diketahui jumlah siswa yang sudah tuntas dalam pembelajaran Ekonomi sebanyak 14 orang (60,87\%) dan siswa yang belum tuntas dalam Berdasarkan hasil analisis data pada siklus II dalam dua kali pertemuan, dengan pokok bahasan pada pertemuan pertama "Menguraikan pengertian bank sentral, tujuan bank sentral, fungsi bank sentral, tugas dan wewenang bank sentral, pengertian sistem pembayaran, peran bank sentral Republik Indonesia dalam sistem pembayaran dan penyelenggaraan sistem pembayaran non pembelajaran Ekonomi sebanyak 9 orang $(39,13 \%)$ dengan Kriteria Ketuntasan Minimal (KKM) yang ditetapkan untuk mata pelajaran Ekonomi di SMA Saraswati Singaraja yaitu 70.

tunai oleh bank sentral " dan pada pertemuan kedua dengan pokok bahasan "Menguraikan sejarah uang, pengertian uang, fungsi uang, jenis uang, syarat uang, pengelolaan uang rupiah oleh bank Indonesia, unsur pengaman uang rupiah, pengelolaan keuangan, pengertian alat pembayaran non tunai, jenisjenis alat pebayaran non tunai". Data aktivitas belajar siswa pada siklus II tampak pada tabel $\quad 4.4 \quad$ berikut

Tabel 4.4 Data Aktivitas Belajar Siswa dalam Mata Pelajaran Ekonomi Siklus II

\begin{tabular}{ccccc}
\hline \multirow{2}{*}{ Kategori } & \multicolumn{3}{c}{ Seberan Aktivitas Belajar Siswa } \\
\cline { 2 - 5 } & \multicolumn{2}{c}{ Pertemuan Pertama } & \multicolumn{2}{c}{ Pertemuan Kedua } \\
\cline { 2 - 5 } & $\begin{array}{c}\text { Jumlah } \\
\text { Siswa }\end{array}$ & Presentase & Jumlah & Presentase \\
\cline { 2 - 5 } Siswa & 5 & $22 \%$ \\
Aktif & 0 & $0 \%$ & 17 & $74 \%$ \\
Cukup Aktif & 5 & $22 \%$ & 1 & $4 \%$ \\
Kurang Aktif & 18 & $78 \%$ & 0 & $0 \%$ \\
Sangat & 0 & $0 \%$ & 0 & $0 \%$ \\
Kurang Aktif & 0 & $0 \%$ & & $100 \%$ \\
Jumlah Siswa & 23 & $100 \%$ & 23 &
\end{tabular}

Hasil belajar pada siklus II menunjukkan bahwa nilai tertinggi yang mampu dicapai oleh siswa adalah 90, sementara nilai terendah yang diperoleh siswa adalah 70. Apabila dibandingkan dengan hasil belajar siklus I, menunjukkan adanya peningkatan terhadap hasil belajar siswa. Hal ini dapat dilihat dari adanya 
peningkatan jumlah siswa yang memperoleh nilai pada rentangan 85-100 sebanyak 9 orang (39,13\%), jumlah siswa yang memperoleh nilai pada rentangan 75-84 sebanyak 12 orang $(52,17 \%)$, dan jumlah siswa yang memperoleh nilai pada rentangan 65-74 sebanyak 2 orang $(8,70 \%)$. Tidak ada siswa yang memperoleh nilai pada rentangan 41-46 $(0,00 \%)$, dan $0-46(0,00 \%)$. Rata-rata hasil belajar siswa pada siklus II adalah 80,65 dengan kategori hasil belajar adalah baik. Data hasil belajar siswa pada siklus II tampak pada tabel 4.5 adalah sebagai berikut.

Tabel 4.5 Data Hasil Belajar Siswa dalam Pembelajaran Ekonomi Siklus II

\begin{tabular}{|c|c|c|c|c|}
\hline No & $\begin{array}{c}\text { Rentangan } \\
\text { Nilai }\end{array}$ & Kategori Nilai & Jumlah Siswa & Persentase \\
\hline 1 & $85-100$ & Amat Baik & 9 & $39,13 \%$ \\
\hline 2 & $75-84$ & Baik & 12 & $52,17 \%$ \\
\hline 3 & $65-84$ & Cukup & 2 & $8,70 \%$ \\
\hline 4 & $41-64$ & Kurang & 0 & $0,00 \%$ \\
\hline 5 & $0-40$ & Sangat Kurang & 0 & $0,00 \%$ \\
\hline \multicolumn{3}{|c|}{ Total } & 23 & $100,00 \%$ \\
\hline
\end{tabular}

Berdasarkan hasil belajar siswa pada siklus II dapat diketahui seluruh siswa tuntas dalam pembelajaran Ekonomi dengan Kriteria Ketuntasan Minimal (KKM) yang ditetapkan untuk mata pelajaran Ekonomi di SMA Saraswati Singaraja yaitu 70. Data ketuntasan belajar siswa pada mata pelajaran Ekonomi pada akhir siklus II dapat dilihat pada tabel 4.6 berikut.

Tabel 4.6 Sebaran Frekuensi Ketuntasan Belajar Siswa pada Mata Pelajaran Ekonomi Siklus II

\begin{tabular}{ccc}
\hline Keterangan & Jumlah Siswa & Presentase \\
\hline Tuntas & 22 orang & $95,65 \%$ \\
Tidak Tuntas & 1 orang & $4,3 \%$ \\
Jumlah & 23 orang & $100,00 \%$ \\
\hline
\end{tabular}

\section{Pembahasan}

Berdasarkan hasil penelitian yang telah dilaksanakan dalam dua siklus dengan penerapan model pembelajaran talking chips, dapat meningkatkan aktivitas dan hasil belajar siswa. Hal ini ditunjukkan dengan adanya peningkatan aktivitas belajar siswa pada siklus I pertemuan pertama, rata-rata nilai aktivitas belajar siswa sebesar 6,70 dan pada pertemuan kedua mengalami peningkatan sebesar 7,52 sehingga nilai rata-rata aktivitas belajar siswa pada siklus I sebesar 7,11 dengan kategori cukup aktif. Meskipun telah terjadi peningkatan aktivitas belajar pada siklus I, akan tetapi hal tersebut menunjukkan bahwa aktivitas belajar siswa masih belum memuaskan sehingga masih perlu untuk diadakan perbaikan. Berdasarkan hasil tindakan, penerapan model pembelajaran talking chips mampu meningkatkan hasil belajar siswa yang dapat dilihat dari adanya kenaikan nilai rata-rata kelas dari 67,70 pada observasi awal, menjadi 70,65 pada akhir siklus I yang berada pada kategori cukup. Ketuntasan belajar klasikal juga meningkat dari 47,83 pada observasi awal menjadi 60,87 pada akhir siklus I.

Pada tindakan siklus II pertemuan pertama rata-rata nilai aktivitas belajar siswa sebesar 7,96 dan pada pertemuan kedua meningkat menjadi 
9,91 sehingga rata-rata nilai aktivitas belajar siswa pada siklus II sebesar 8,93 dengan kategori aktif dibandingkan pada siklus I. Hal ini menunjukkan bahwa aktivitas belajar siswa mengalami peningkatan dari sebelumnya. Sistem pembagian anggota kelompok diskusi secara acak oleh guru, pemberian tambahan nilai atau reward kepada siswa yang aktif dalam kegiatan pembelajaran dengan model pembelajaran talking chips ternyata dapat meningkatkan aktivitas belajar siswa. Penentuan anggota kelompok secara acak oleh guru mampu menciptakan situasi diskusi kelompok yang lebih baik, dimana setiap siswa yang memiliki kemampuan lebih dalam kelompok tersebut dapat langsung membantu menjelaskan materi atau permasalahan yang belum dimengerti oleh anggota kelompok yang memiliki kemampuan kurang, sehingga mampu menciptakan suasana belajar yang tidak menegangkan sehingga siswa mampu untuk mengkontruksi pemahaman yang dimiliki dengan materi yang sedang dipelajari melalui serangkaian pertanyaan yang diberikan oleh guru. Kemudian nilai rata-rata hasil belajar siswa pada siklus II mengalami peningkatan yang cukup tinggi dari 70,65 pada akhir siklus I menjadi 80,65 pada akhir siklus II dengan kategori baik.

Dengan adanya penerapan model pembelajaran talking chips menunjukkan terjadinya peningkatan aktivitas dan hasil belajar siswa. Hal ini ditunjukkan dengan peningkatan skor rata-rata aktivitas belajar siswa pada siklus I sampai dengan siklus II sebesar 1,82. Skor rata-rata hasil belajar siswa pada siklus I sampai dengan siklus II juga mengalami peningkatan dengan rata-rata kenaikan sebesar 10,00.

Berdasarkan analisis data aktivitas dan hasil belajar siswa yang diperoleh pada siklus I sampai dengan siklus II tersebut, maka pelaksanaan tindakan yang dilakukan dapat dikatakan mampu meningkatkan aktivitas dan hasil belajar siswa kelas X SMA Saraswati Singaraja tahun pelajaran $2017 / 2018$. Hal ini dapat 3) mengalami peningkatan sebesar $13,04 \%$ dari $47,83 \%$ pada observasi awal menjadi $60,87 \%$ pada akhir siklus terjadi karena penerapan model pembelajaran talking chips dapat membantu siswa secara aktif baik fisik maupun psikologis dalam setiap kegiatan pembelajaran, sehingga mampu untuk meningkatkan hasil belajar Ekonomi siswa. Hal ini sejalan dengan pendapat (Barkley, dkk) yang menyatakan bahwa model pembelajaran talking chips cocok diterapkan dalam proses pembelajaran, hal ini disebabkan karena model pembelajaran ini bertujuan untuk mendorong siswa untuk berbicara.

Dari paparan di atas, secara umum model pembelajaran talking chips telah dapat meningkatkan aktivitas dan hasil belajar siswa kelas X SMA Saraswati Singaraja. Dengan kata lain, penelitian ini sudah dapat menjawab pertanyaan dari rumusan masalah sehingga penelitian ini dapat dikatakan berhasil.

\section{SIMPULAN DAN SARAN Simpulan}

Berdasarkan

has

dan

pembahasan yang telah dilakukan, maka dapat disimpulkan hal-hal sebagai berikut.

1) Penerapan model pembelajaran kooperatif tipe talking chips dapat meningkatkan aktivitas belajar siswa pada mata pelajaran Ekonomi siswa kelas $X$ di SMA Saraswati Singaraja. Rata-rata nilai aktivitas belajar siswa pada siklus I sebesar 7,11 berada dalam kategori cukup aktif, sedangkan rata-rata nilai aktivitas belajar siswa pada siklus II sebesar 8,93 yang berada dalam kategori aktif.

2) Penerapan model pembelajaran kooperatif tipe talking chips dapat meningkatkan hasil belajar siswa pada mata pelajaran Ekonomi siswa kelas $X$ di SMA Saraswati Singaraja. Pada siklus I nilai rata-rata hasil belajar siswa sebesar 70,65 yang berada dalam kategori cukup, jumlah siswa yang sudah tuntas sebanyak 14 orang $(60,87 \%)$ dan jumlah siswa yang belum tuntas sebanyak 9 orang $(39,13 \%)$. Ketuntasan belajar klasikal I, sedangkan pada siklus II nilai ratarata hasil belajar siswa mengalami peningkatan menjadi 80,65 yang 
berada pada kategori baik, jumlah siswa yang sudah tuntas sebanyak 22 orang $(95,65 \%)$ dan jumlah siswa yang belum tuntas sebanyak 1 orang $(4,35 \%)$. Ketuntasan belajar klasikal juga mengalami peningkatan yang dapat dikatakan sangat tinggi yaitu sebesar $34,78 \%$ dari $60,87 \%$ pada akhir siklus I menjadi $95,65 \%$ pada akhir siklus II.

\section{Saran}

Berdasarkan simpulan yang dipaparkan diatas, maka dapat diungkapkan saran terkait dengan hasil penelitian ini adalah sebagai berikut.

1. Disarankan kepada guru SMA Saraswati Singaraja agar dapat menerapkan model pembelajaran kooperatif tipe talking chips sebagai salah satu model pembelajaran yang dipilih dalam pembelajaran Ekonomi. Karena model pembelajaran kooperatif tipe talking chips ini dapat meningkatkan aktivitas dan hasil belajar siswa sehingga tujuan pembelajaran yang diharapkan dapat tercapai.

2. Untuk memaksimalkan penerapan model pembelajaran kooperatif tipe talking chips perlu adanya reward agar siswa lebih semangat, sehingga dapat meningkatkan aktivitas dan hasil belajar siswa.

3. Untuk peneliti selanjutnya hendaknya lebih memperluas lagi penelitian tentang model pembelajaran kooperatif tipe talking chips. Dengan menggunakan pokok bahasan yang berbeda untuk mengetahui efektivitas pengimplementasian model pembelajaran kooperatif tipe talking chips serta memperhatikan kendala-kendala yang dihadapi peneliti sebagai bahan pertimbangan untuk perbaikan dan penyempurnaan pelaksanaan penelitian berikutnya.

\section{DAFTAR PUSTAKA}

Barkley, Elizabert E., dkk. 2012. Collaborative Learning Techniques. Bandung: Nusamedia.

Candiasa, I Made. 2011. Pengujian Instrumen Penelitian disertai Aplikasi Iteman dan Bigsteps. Singaraja: Undiksha Press

Dantes, Nyoman. 2012. Metode Penelitian. Yogyakarta: C.V Andi Offset.

Departemen Pendidikan Nasional. 2003. Kurikulum Tingkat Satuan Pendidikan (KTSP): Sistem Pendidikan Nasional. Jakarta

Dimyati dan Mudjiono, 2002. Belajar dan Pembelajaran. Jakarta: Rineka Cipta.

Fathurrohman, Muhammad. 2015. ModelModel Pembelajaran Inovatif. Jogjakarta: Ar - Ruzz Media.

Huda, Miftahul. 2013. Model-model Pengajaran dan Pembelajaran. Yogyakarta: Pustaka Pelajar.

Isjoni. 2014. Cooperative Learning. Bandung: Alfabet.

Koyan, I Wayan. 2009. Statistik Dasar dan Lanjut (Teknik Analisis Data Kuantitatif). Singaraja: Universitas Pendidikan Ganesha.

Lie, Anita. 2008. Cooperative Learning. Jakarta: PT Gramedia Widiasarana.

Ngalimun. 2014. Stratgi dan Model Pembelajaran. Yogyakarta : Aswaja Pressindo.

Pardiani, Luh Gede. 2013. Pengaruh Model Pembelajaran Teknik Talking Chips Terhadap Hasil Belajar IPS Siswa Kelas V SD Di Gugus I Kecamatan Pupuan Kabupaten Tabanan Tahun Pelajaran 2012/2013. Undiksha.

Slameto, 2003. Belajar dan Faktor-Faktor Yang Mempengaruhi. Jakarta: PT Rineka Cipta.

Sugiyono. 2008. Metode Penelitian Pendidikan (Pendekatan 
Kuantitaif, Kualitatif, dan $R \& D)$. Bandung: Alfabeta.

Sukardi. 2009. Metode Penelitian

Pendidikan. Jakarta: PT Bumi Aksara.

Sukesih, E. 2013. "Pengertian, Definisi Hasil Belajar Menurut Para Ahli. Tersedia pada: http://esihkeyc.blogspot.co.id/2013/ 03/pengertian-definisi-hasilbelajar.html. diunduh 10 Januari $\underline{2016}$

Susanto, Ahmad. 2013. Teori Belajar dan Pembelajaran. Jakarta: Prenadamedia Group.

Susilo. 2011. Aktivitas-aktivitas Belajar Siswa. Tersedia pada http//:sisilofy.wodpress.com (diakses pada tanggal 22 Mei 2015).

Trianto. 2009. Mendesain Model Pembelajaran Inovatif-Progresif. Jakarta: Kencana Prenada Media group. 